\title{
Bacterial Endocarditis in Children : Clinical and Laboratory Findings, and the Role of Echocardiography in Its Diagnosis and Management
}

\author{
by
}

SUDIGDO SASTROASMORO, BAMBANG MADIYONO, ISMET N. OESMAN, and SUKMAN TULUS PUTRA

(From the Department of Child Health, Medical School, University of Indonesia/Ciplo Mangunkusumo Hospital, Jakarta)

\begin{abstract}
We report clinical and laboratory findings of 15 children with bacterial endocarditis, admitted to the Department of Child Health, University of Indonesia/Cipto Mangunkusumo Hospital from February, 1987 to June, 1989.

There were 8 boys and 7 girls with bacterial endocarditis, ranging in age from 10 weeks to 16 years. The diagnosis was suspected because of prolonged fever, with or without other manifestations, i.e. congestive heart failure, refractory anemia, or paroxysmal atrial tachycardia. The underlying heart disease was congenital in I 2 cases and rheumatic heart disease in 3 cases.

The clinical, electrocardiographic, and radiologic manifestations were generally predominated by the pre-existing hearl disease. No 'characteristic' findings of bacterial endocarditis, i.e. Osler's nodes, Janeway lesions or splinter haemorrhages were detected. Posi!ive bacterial culture was obtained in 12 cases; the most frequent bacteria isolated was Pseudomonas aeruginosa (4 cases). Streptococcus viridans was isolated in 2 cases only.

Vegetation was visualized echocardiographicaily in 12 cases; 9 with clear cut evidence of large vegetution, and in the other 3 the vegetation was equivocal. On follow-up they disappeared grudually with clinicul improvement. Large vegetation might need 2 full months to disappear echocardiographically.
\end{abstract}


It is concluded that bacterial endocarditis is not a rare complicution of structural heart disease in our hospital, with a high mortality rate. The availability of govd resolution echocardiography has been very helpful in establishing the diagnosis as well as in following-up patients with bacierial endocarditis. 


\section{Introduction}

Bacterial endocarditis (BE) is one of the major threats in patients with structural heart disease. Reports on the incidence of this disease have been controversial; some authors reported increasing incidence of the disease (Johnson et al., 1979, Kaplan et al. 1979), while other authors reported that the incidence was declining in accordance with better prophylactic management (Zakrzewski and Keith, 1965; Caldwell et al., 1971; Johnson et al., 1975; Johnson and Rhodes, 1982; Geva and Frand, 1988).

To the best of our knowledge there was no published data to approximate the incidence of $\mathrm{BE}$ in the paediatric population in Indonesia. Similarly, we are not aware of any publication concerning the clinical and laboratory manifestations of $\mathrm{BE}$ in Indonesia.

One of the many obstacles in the diagnosis of $\mathrm{BE}$ in developing countries has been the lack of good microbiological laboratory to perform serial blood culture needed for the diagnosis of this disease. Echocardiography has been very useful in the diagnosis and management of patients with BE (Dillion at al., 1973; Robbins et al., 1985; Lutas et al., 1985; Muller-Haake, 1987; Geva and Frand, 1988). We report our experience with 15 cases of BE with specific reference to the use of echocardiographv in its diagnosis and management.

\section{Materials and Methods}

\section{Patients}

Consecutive patients with clinically proved $\mathrm{BE}$, admitted to the Department of Child Health, Cipto Mangunkusumo Hospital, Jakarta, between February, 1987, and June, 1989, comprise the study population.

\section{Clinical and laboratory data}

Complete history was obtained and thorough physical examination performed in every patient. $\Lambda$ complete 13-lead electrocardiogram (ECG) was obtained, as wcre standard anterior-posterior chest $X$ ray $(C X R)$, complete blood examination, and erythrocyte sedimentation rate (ESR). Routine blood, ESR, and ECG examinations were repeated weekly; unless otherwise indicated, CXR was repeated every 4 weeks.

Blood cultures (at least 3 occasions in 2 days) were performed to lind out the of- fending microorganisms, including anaerobic bacteria, but not for fungi. In patients who had been on antibiotic treatment, the antibiotics were withheld for 3 days prior to blood culture examination. Patients with rheumatic heart disease were explored for the possibility of rheumatic reactivation by performing anti-sreptolysin $\mathrm{O}(\mathrm{ASO})$ and $\mathrm{C}$-reactive protein (CRP) examinations, and throat swab culture to find olt group $\wedge$ Streptococcus beta-haemolyticus.

Echocardiography was done on admission, using Aloka SSD-720 Sector Scanner (before November 1988) or Toshiba SSH 65-A Duplex Scanner with Doppler and color - flow coding (from November 1988 and thereafter), with 5 or/and $3.75 \mathrm{MHz}$ tranducers. M-mode and 2-dimensional echocardiographic examinations were performed both for the diagnosis of the struc- 
tural heart disease and to search the presence of vegetation. Doppler study and color flow mapping were performed after November, 1988 when the machine was available. Echocardiographic examination was repeated in an interval of 3 to 7 days throughout the treatment period, to follow the progress of the vegetation.

\section{Management}

All patients were initially put in intravenous fluid drip with normal saline or $5.10 \%$ of dextrose. Soon after clinical condition permitted, oral feeding was resumed. Patients with congestive heart failure were treated with oral digoxin or intravenous deslanosid-C $0.03 \mathrm{mg} / \mathrm{kg}$ body weight/day in divided doses for the first day, then followed by $0.01 \mathrm{mg} / \mathrm{kg}$ body weight/day orally, and furosemide 1 to 2 $\mathrm{mg} / \mathrm{kg}$ body weight/day orally or intravenously.
Antibiotics were administered immediately after blood culture specimens were obtained. The initial antibiotics used were a combination of intravenous ampicillin, $200 \mathrm{mg} / \mathrm{kg}$ body weight/day, and chlo. ramphenicol, $75-100 \mathrm{mg} / \mathrm{kg}$ body weight/ day. Whenever feasable the antibiotics were changed in accordance with the result of blood culture and sensitivity tests. After definite clinical improvement the antibiotics were given orally. The duration of treatment in the survivals varied with the clinical and laboratory assessments, ranging from 25 days to 7 weeks.

Other supportive measures were given upon indication, e.g. packed red cells transfusion in severely anemic patients, or correction of acid base and electrolyte imbalances.

Surgery was of fered to the parents when indicated. No autopsy study was done.

\section{Results}

There werc 15 patients ( 8 boys and 7 girls) with $\mathrm{BE}$ in the study period, ranging in age from 10 weeks to 16 years. The age and sex distribution of the 15 cases is depicted in table 1 .

All patients had pre-existing heart disease; most of them (10 patients) had been under our observation in out-patient clinic, whereas the other 5 had never been examined in our clinic before. Table 2 shows the pre-existing heart disease in the 15 patients.

Table 1 : Age and sex distribution of 15 cases with bacterial endocarditis

\begin{tabular}{cccc}
\hline Age group (yrs) & Male & Female & Total \\
\hline$<5$ & 2 & 2 & 4 \\
\hline $5-$ & - & 3 & 3 \\
\hline $10-$ & 6 & 2 & 8 \\
\hline To । a 1 & 8 & 7 & 15 \\
\hline
\end{tabular}


Table 2: Pre-existing heart disease in 15 patients with bacterial endocarditis

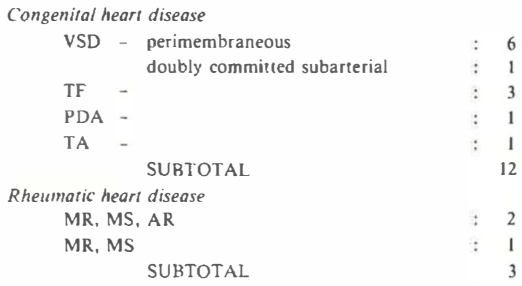

TO T A L

Abbreviations : $\mathrm{VSD}=$ ventricular septal defect; $\mathrm{TF}=$ tetralogy of Fallot; $\mathrm{PDA}=$ patent ductus arteriosus; $\mathrm{TA}=1$ ricuspid atresia; $\mathrm{MR}=$ mitral regurgitation; $\mathrm{MS}=$ mitral stenosis; $\mathrm{AR}=$ aortic regurgitation.

Clinical manifestations

Fever was the only symptom found in $100 \%$ of patients. Other symptoms reported were (in decreasing order): easy fatiguability, poor appetite, shortness of breath, weight loss, profuse sweating, vomiting, and chills (see table 3).

Physical findings were largely dominated by signs of the underlying heart disease. In one patient with PDA, besides classical contlnous murmur, a loud systolic murmur and loud diastolic murmur following accentuated second heart sound were also heard. At surgery, a large VSD was also found, probably because of perforation of the ventricular septum.

Patients with congestive heart failure showed classical clinical findings.

Table 4 shows clinical signs of patients with bacterial endocarditis.

Table 3: Symptoms of bacterial endocarditis in 15 patients

\begin{tabular}{lcc}
\hline Symptom & No of Patients & Percentage \\
\hline fever & 15 & $100.0 \%$ \\
easy fatiguability & 12 & $80.0 \%$ \\
poor feeding & 12 & $80.0 \%$ \\
dyspnea & 6 & $40.0 \%$ \\
weight loss & 4 & $26.7 \%$ \\
profusc swcaring & 3 & $20.0 \%$ \\
vomiting & 3 & $20.0 \%$ \\
chills & 2 & $13.3 \%$ \\
\hline
\end{tabular}


Table 4: Physical findings in 15 patients with bacterial endocarditis *

$\begin{array}{lrr}\text { Prolonged fever } & 15 & 100.0 \% \\ \text { Paleness } & 9 & 60.0 \% \\ \text { Congestive heart failure } & 6 & 40.0 \% \\ \text { Petechiac } & 5 & 33.3 \% \\ \text { Splenomegaly } & 2 & 13.3 \% \\ \text { Changing or new murmurs } & 1 & 6.7 \%\end{array}$

*) excluding typical signs of pre-existing heart disease such as abnormal heart sounds and murmurs, or cyanosis and clubbed fingers in patients with cyanotic congenital heart disease.

\section{Electrocardiographic changes}

In most of the 10 patients who had had records of ECG before, there were no significant changes in the ECG when they were admitted for BE. However, 3 patients presented with paroxysmal atrial tachycar. dia (PAT), which could be easily managed by digoxin. After resumed to sinus rhythm, ECG tracings showed essentially the same as before. In a 7-year old patient with PDA, the ECG changes were quite remarkable. Her last ECG tracing was made when she was 3 years old, which only showed left ventricular hypertrophy. When she was admitted in October, 1988 for BE, her ECG showed right axis deviation, biventricular hypertrophy (RVH predominant), and right atrial enlargement.

The ECG's of patients with tetralogy of Fallot, tricuspid atresia, and rheumatic heart disease were similar to their previous ones.

\section{Radiologic changes}

In 10 patients who had had record of CXR before, we noted that there was no appreciable CXR changes when they were admitted for BE. All patients with rheumatic heart disease (mitral regurgitation, mitral stenosis, and aortic regurgitation) showed cardiomegaly with some degree of pulmonary congestion, as had been noted before. In all of 4 patients with small VSD, both perimembraneous and subarterial, the heart shadow still normal with normal or minimal increase in pulnonary blood flow.

Patients with tetralogy of Fallot, 2 of them had been under our observation, showed typical coer en sabot cardiac shadow with decreased vascular markings. One patient with PDA, aged 7 years, had been diagnosed of having PDA when she was 3 years old. She was recommended for surgery but the parents refused, and was then lost for follow up for almost 4 years. She was then referred by a private hospital with full-blown cardiac failure with gross cardiomegaly and severe ECG changes. She died on table of severe heart failure.

\section{Bacterial culture}

Bacterial culture was done in every patient. The culture was negative in 3 patients. The remaining 12 showed bacterial growth, (10 with single bacteria and 2 with two bacteriae). The most common bacteria isolated was Pseudomonas aeruginosa (4); the 'classical' etiological microorganism of bacterial cndocarditis, Streptococcus viridans, was only recovered in 2 cases (tablc 5). 
Table 5: Resutts of bacterial culture in 15 patienis with bacterial endocarditis*

Microorganism

$\begin{array}{lr}\text { Pseudomonas aeruginosa } & 4 \\ \text { Streptococcus viridans } & 2 \\ \text { Klebsiella pneumoniae } & 2 \\ \text { Escherichia coli } & 2 \\ \text { Staphylococcus aureus } & 2 \\ \text { Streptococcus epidermidis } & 2 \\ \text { No growth } & 3\end{array}$

No. of Positive Culture

*) In 2 patients, 2 microorganisms were isolated in each.

\section{Laboratory findings}

The hemoglobin content in the 15 patients ranged from 4.2 to $15.5 \mathrm{~g} / \mathrm{dl}$. When the "normally" polycythemic patients (patients with tetralogy of Fallot and tricupid atresia) were excluded, the hemoglobin content ranged from 4.2 to $12.6 \mathrm{~g} / \mathrm{dl}$. Most of them (8 patients) showed a hemoglobin content of less then $10 \mathrm{~g} / \mathrm{dl}$ on the initial examination; in 2 of them it was less than $5 \mathrm{~g} / \mathrm{dl}$. Most of the non-cyanotic patients showed the hemoglobin content between 6 and $9.8 \mathrm{~g} / \mathrm{dl}$.

Leukocytosis (WBC of more than 10.000/ cu $\mathrm{mm}$ ) was only detected in $6(40 \%)$ patients (from 12.600 to $17.000 / \mathrm{cu} \mathrm{mm}$ ). The majority of cases showed WBC between 6.100 to $9.600 / \mathrm{cu} \mathrm{mm}$.

Blood sedimentation rate was increased in all of bur patients; at times it was as high as $128 \mathrm{~m} 1 \mathrm{~m} /$ hour. The rate gradually decreased with clinical improvement; however, many of them still showed abnormal ESR by the end of the second month of treatment, in spite of definite clinical improvement.

Table 5 summarizes the laboratory findings in patients with $\mathrm{BE}$.

Table 6: Summary of laboratory findings in 15 patients with bacterial endocarditis
Anemia $(\mathrm{Hb}<10 \mathrm{~g} / \mathrm{dl})$
$\mathrm{Hb}^{<} \mathrm{s}-9.9 \mathrm{~g} / \mathrm{dl}$
- 2 cases
- 6 cases
Leukocytosis
(WBC $>10.000 / \mathrm{cu} \mathrm{mm}$ )
- 6 cases
Increased ESR
- 13 cases
Positive CRP $(+$ to +++$)$
- 13 cases

\section{Echocardiographic findings}

Initial echocardiographic investigation was done on the first or second day of admission. We were able to demonstrate de- finite 'abnormal mass' attached to the endocardium of the ventricular septal surface of the right ventricle, aortic surface, or atrioventricular surface in 9 patients. In 
2 patients we were not sure about the abnormality of the mass on initial examination, because it was considered might be a normal structure. On follow up, however, the masses in question were decreasing gradually with the improvement of clinical condition. In 4 patients we were unable to demonstrate the vegetation, even after repeated echo examinations.

Features of site and size of vegetation are presented in table 7 .

Table 7: Site and size of vegetation as seen echocardiographically in 15 patients with bacterial endocarditis.

\begin{tabular}{lcccc}
\hline $\begin{array}{l}\text { Heart } \\
\text { Disease }\end{array}$ & $\begin{array}{c}\text { No. of } \\
\text { Patients }\end{array}$ & $\begin{array}{c}\text { No of }(+) \\
\text { Vegetation }\end{array}$ & $\begin{array}{c}\text { Sitc of } \\
\text { Vegetation }\end{array}$ & $\begin{array}{c}\text { Size of } \\
\text { Vegetation }\end{array}$ \\
\hline VSD & 7 & 6 & RVOT & $5-16 \mathrm{~mm}$ \\
TF & 3 & 2 & RVOT & $8-10 \mathrm{~mm}$ \\
PDA & 1 & 1 & Ao-L & $15 \mathrm{~mm}$ \\
TA & 1 & - & - & - \\
RHD & 3 & 2 & RVOT (I) & $12 \mathrm{~mm}$ \\
& & & AML (1) & $10 \mathrm{~mm}$ \\
\hline
\end{tabular}

Note: (a) Abbreviations: RVOT = right tentricular outflow tract; $A 0-L=$ aortic leaflet: $\Lambda \mathrm{ML}=$ anterior leaflet of mitral valve. For other abbreviations see table 2.

(b) The size of vegetation indicates the approximation of the largest diameter of the vegetation as seen with composite views. At times the vegetation looked like a band, as seen in a case with PDA.

Representative of echocardiographic ap- pearance of vegetation in presented in fig 1 .

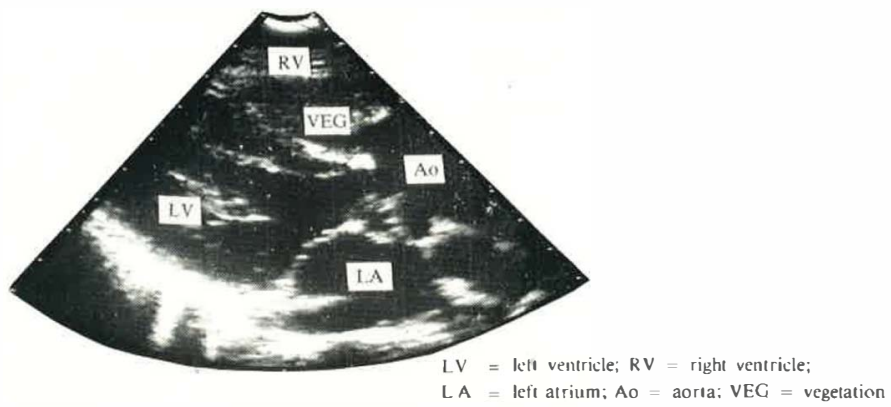

Fig. 1. Echocardiographic appearance of a large vegetation in a patient with small perimembraneous VSD. Note the shaggy appearance of the mass. 
In most patients, the size of vegetation was relatively unchanged in the first 2 weeks of treatment. After then, the vegetation size became gradually decrease, and then was invisible echocardiographically after 4 weeks or more. One patient with large vegetation necded 8 weeks before the vegetation disappear

\section{Outcome}

Six patients died 2 days to 2 wceks after the comencement of treatment. A patient with large PDA who presented with severe cardiac failure succumbed on the operation table. Two patients with severe valvular heart disease died following severe intractable congestive heart failure despite vigorous treatment with decongestants. Two patients with large VSD (aged 2 and a half months and 11 years) and the patient with tricuspid atresia also died of intractable heart failure.

All patients without carciac failure survived. Onc patient with small VSD underwent successful surgery several months after recovered from BE. Other patients were followed in o:sr out-patient clinic for further management.

\section{Discussion}

There have been conflicting reports on the incidence of BE iti children. Some authors believed, that $i \because$ spite of the availability of antibiotics to prevent $\mathrm{BE}$ in children with structural heart disease, it was apparent that no definite decrease of the incidence of BE was observed (Johnson et al., 1975; Kaplan, 1977). In fact some authors belicved that reports of this life threatening complication of structural heart disease has been increasing in recent years, although it does not always mean that there was a true increase of the incidence; rather, it would indicate that more diagnosis has been cstablished with increasing awareness and better method of examination (Zakraewski and Keith, 1965; Johnson ct al, 1979). On the other hand, recent report of Geva and Frand (1988) indicated that there was a significant decrease of incidence of $\mathrm{BE}$ in the last decade in their hospital.

There wcre 15 patients with BE in our department in 17 months period. In the same period, there were 11.086 pediatric admissions; the relative incidence therefore was I in 740 admission. This incidence was quite high when compared with other reports. Kaplan and Shulmarı (1983) reviewed the literature and found that the incidence of BE was between 1800 and 4500 pediatric admissions. Recent report of Geva and Frand stated that the incidence of $\mathrm{BE}$ in their hospital in Tel Aviv was 1 in 1806 admissions between 1964 and 1975 , and 1 in 6725 between 1975-1984. We believe this high incidence of $\mathrm{BE}$ in this series, actually represent our increase of awareness to the disease.

Indeed, the diagnosis of $\mathrm{BE}$ has been very difficult, because fever, which is the most consistent symptom, frequently unnoticed by parents, especially those with low ediscation level. In addition, signs of BE which are non specific, i.e. paleness, poor appetite, decrease exercise tolerance, and others, may be appreciated by parents and physicians as 'normal' for children with cardiac problem. The diagnosis can only be established with high degree of suspicion, and by careful assessment of history, physical findings, and proper blood culture examination.

Our seriesindicated that the most consis- 
tent symptom was prolonged fever, which was usually of low grade. Other complaints were not specific, e.g. resembling any systemic infectious diseases. In this series, as seen in table 4 , the physical examination also did not show any characteristic for this disease. In contrast to the literature, we did not mention any characteristic findings such as Osler node, Janeway lesions, or splinter haemorrhages. Similarly, changing murmur or development of new murmur was not found in this series, except in one patient with PDA who definitely showed marked physical deterioration with the development of pulmonary hypertension and severe aortic regurgitation. In short, in almost all patient we had known before, no significant murmur change could be appreciated.

Changes of ECG's and chest X-rays were not impressive in most of our patients. All patients with small VSD did not show any change in the chest $\mathrm{X}$-ray appearance. The one patient with PDA definitely showed enlargement of the heart when relatively compared with the previous picture. In this patient, the ECG also showed gross change, consistent with the definite deterioration of the patients condition. The 4 patients with severe valvular heart disease had had enlarged heart with some degree of pulmonary congestion when they were seen in the outpatient clinic. On admission, they showed enlarged heart with more prominent pulmonary vascular congestion, indicating the increase in the degree of heart failure. It is quite difficult to be sure that there was an increase of the murmur, but we were sure that there was no new murmur develop.

Since the report of Dillon et al. (1973) on the use of M-mode echocardiography to detect $\mathrm{BE}$ vegetation, there have been enthusiastic reports supporting the role of echocardiography in the management of
BE. The development and wide use of 2dimensional echocardiography has refined the ability of echocardiography to detect the vegetation (Wann et al., 1979; Meltzer and Roelandt, 1981). The success of echocardiography for this purpose range from 13 to $78 \%$ (Lutas et al., 1986).

In our series we could say with confidence the presence of vegetation by 2 dimensional echocardiography in 11 out of the 15 patients. Most of the vegetations were seen at the endocardial surface of the RVOT, measuring from $5 \mathrm{~mm}$ to $18 \mathrm{~mm}$. In 2 patients, we were at first not very sure about the vegetation, because the structure observed was considered probably normal structure. But on follow-up, the structure became gradually decrease in size as clinical condition improved, and at last disappeared. We concluded that the vegetation was actually there at initial examination.

The reliability of echo visualization has been varied. In our experience, when the vegetation is large and freely moving, especially if it is attached to the atrioventricular or semilunar valve, we could state with great confidence that the structure is bacterial vegetation. But if the vegetation is small, and if it is attached to the ventricular septum, we can not be ascertained that the struture was a vegetation. In this situation, frequent repeated echo examinations should be performed to follow the structure in question.

The mortality rate in our series was quite high $(40 \%)$, conformed with other results of many authors. Although our series is not large enough to draw definite conclusion, we note that the mortality associated well with the presencc of congestive heart failure. All patients who died had definite signs of congestive heart failure, and we found that it was quite difficult to treat. All patients without heart failure survived, including 3 patients with paroxysmal atrial 
tachycardia. The mortality was not apparently correlated with the presence, site and size of the vegetation; rather, it was correlated with the presence of severe congestive heart failure. This finding is in agreement with that of Lutas et al. (1986), and in contrast with some other reports that there was a correlation between the presence of echocardiographic evidence of vegetation and the complication rate and death of patients with $\mathrm{BE}$.

In conclusion, infective endocarditis is not a rare complication of structural heart disease in our hospital. Symptoms and signs are usually not specific; indeed we did not find well-known characteristic signs such as Osler nodes, Janeway lesions, or splinter hemorrhages in any of our 15 patients. High index of suspicion is a sine qua non if early diagnosis is to be established. Isolation of the offending microorganism is a prerequisite for both the diagnosis and management of patients with BE. However, this procedure is not available in most Indonesian hospitals. A good resolution echocardiography will be of much value. In the presence of clinical evidence of BE, visualization of vegetation with echocardiography will sirongly support the diagnosis of $\mathrm{BE}$, so that initial treatment with high dose antibiotics can be started early without awaiting the result of blood culture.

\section{REFERENCES}

1. CALDWELl, R.L.; SHACHAR, B; LIEBMAN, J.: Subacute bacterial endocarditis in infants and children : Current status. Amer. J. Dis. Child. 122: 312-316 (1971).

2. DILLON, J.C.; FIEGENBAUM, H.; KONECKE, L.; DA VIS, R.H.; CHANG, S.: Echocardiographic manifestations of valvular vegetations. Amer. Heart J. 86: 698-704 (1973).

3. GEVA, T.; FRAND, M.: Infective endocarditis in children with congenital heart disease: the changing spectrum, 1965-1985. Eur. Heart J. 9: 1244-1249 (1988).

4. JOHNSON, C.M.; R.HODES, K.H.: Pediatric endocarditis. Mayo Clin. Proc. 57: 86-92 (1982).

5. JOHNSON, D.H.; ROSENTHAL, A.; NADAS, A.S.: Bacterial endocarditis in children under 2 years of age. Amer. J. Dis. Child. 129: 183-186 (1975).

6. JOHNSON, D.H.: ROSENTHAL, A.; NADAS, A.S.: A forty-years review of bacterial endocarditis in infancy and childhood. Circulation 51: $581-580$ (1979).

7. KAPLAN, E.L.; RICH, H.; GERSONY, W.; MANNING, J.: A collaborative study of infective endocarditis in the 1970's. Emphasis on infections who have undergone cardiovascular surgery. Circulation 59: 327-339 (1979).

8. KAPLAN, E.L.; SHULMAN, S.T.: Endocar- ditis; in ADAMS, EMMANOULIDES, Moss Heart Disease in Infants, children, and adolescents, 3rd. ed., pp. 565-576 (Williams \& Wilkins, Baltimore/London 1983).

9. LUTAS, E.M.; ROBERTS, R.B.; DEREVEUX, R.B.; PRIETO, L.M.: Relation between the presence of echocardiographic vegetations and the complication rate in infective endocarditis. Amer. Heart J. 112: 107-113 (1986).

10. MELTZER, R.; ROEL.ANDT, J.: Cardiac catheterization and echocardiography in infective endocarditis. Amer J. Cardiol. 47: 1183-1186 (1981).

11. MULler-HAAKE, R.C.; MiNAlE, C.; STEINKAMP, H-J.; BARDOS, P.: Therolcof echocardiography in the diagnosis of acute infective endocarditis. Lur. Heart J. 8 (Suppl): 293.298 (1987).

12. ROBBIN, M.J.; SOEIRO, R.; FRISHMAN, W.H.; STROM, J.A.: Right-sided valvular endocarditis: Etiology, diagnosis, and an approach to therapy. Amer. H.J. 111: 128-135 (1985).

13. WANN, L.S.; HALLAM, C.C.; DILLON, J.C.; WEIMAN, A.E.; FIECJENBAUM, H.: Comparison of $\mathrm{M}$-mode and cross sectional echocardiography in infective endocarditis. Circulation 60: $728-734$ (1979). 